\title{
SISTEM MEDIASI DALAM PERADILAN ADAT ACEH
}

\author{
Mulyadi Nurdin \\ Dosen Fakultas Ekonomi dan Bisnis IAIN Langsa \\ mulyadinurdin@gmail.com
}

\begin{abstract}
Abtract. Adat as a traditional justice system, is one way to resolve disputes in the community peacefully ou tside the court, through a process of mediation or peace. The tradition which is Indonesian wisdom continues to live and develop. But in its implementation it often faces various problems, suchas, obstacles to the recognition of customary court decisions by law enforcement, as well as synchronization between judicial institutions. The mediation system through customary justice if properly functioned, will solve various problems quickly, cheaply and fairly. Various problems that occur, related to customary justice, can be resolved, if there are good wishes between state institutions.
\end{abstract}

\begin{abstract}
Abstrak. Peradilan adat merupakan salah satu cara penyelesaian sengketa dalam masyarakat secara damai di luar pengadilan, melalui proses mediasi atau perdamaian. tradisi yang merupakan kearifan luhur bangsa Indonesia tersebut terus hidup dan berkembang, namun dalam pelaksanaannya kerap kali menghadapi berbagai permasalahan seperti kendala pengakuan putusan peradilan adat oleh penegak hukum serta sinkronisasi antar lembaga peradilan. Sistem mediasi melalui peradilan adat jika difungsikan dengan baik akan menyelesaikan berbagai masalah dengan cepat, murah, dan adil. Berbagai permasalahan yang terjadi terkait peradilan adat sangat mungkin untuk diselesaikan jika ada iktikad baik antar lembaga negara.
\end{abstract}

Kata Kunci: Mediasi, Adat, Hukum

\section{Pendahuluan}

Mediasi secara etimologi berasal dari bahasa latin, mediare yang berarti berada di tengah. Makna ini menunjuk pada peran yang ditampilkan pihak ketiga sebagai mediator dalam menjalankan tugasnya menengahi dan menyelesaikan sengketa antara para pihak.

Berada di tengah juga bermakna mediator harus berada pada posisi netral dan tidak memihak dalam menyelesaikan sengketa. Ia harus mampu menjaga kepentingan para pihak yang bersengketa secara adil dan sama sehingga menumbuhkan kepercayaan dari para pihak yang bersengketa ${ }^{1}$. Dalam Collins English Dictionary and Thesaurus disebutkan bahwa mediasi adalah, "kegiatan menjembatani antara dua pihak yang bersengketa guna menghasilkan kesepakatan (agreement)"2.

1 Syahrizal Abbas, 2009, Mediasi dalam Perspektif Hukum Syari'ah, Hukum Adat dan Hukum Nasional, Kencana Prenada Media Group, Jakarta, halaman 2

${ }^{2}$ Lorna Gilmour, 2007, Penny Hand dan Cormac McKeown (eds), Collins English Dictionary and Thesaurus, Third Edition, Harper Collins Publishers, Great Britain, halaman 510. 
Dalam kamus Besar Bahasa Indonesia, kata mediasi diberi arti sebagai "proses pengikutsertaan pihak ketiga dalam penyelesaian suatu perselisihan sebagai penasihat"3.

Berdasarkan penjelasan mediasi dari segi kebahasaan di atas lebih menekankan pada keberadaan pihak ketiga yang menjembatani para pihak bersengketa untuk menyelesaikan perselisihannya. Penjelasan ini sangat penting untuk membedakan proses penyelesaian sengketa dengan bentuk penyelesaian seperti arbitrase, ajudikasi dan lain-lain. Mediator berada pada posisi di tengah dan netral antara para pihak yang bersengketa dan mengupayakan menemukan sejumlah kesepakatan sehingga mencapai hasil yang memuaskan para pihak yang bersengketa.

Penjelasan mediasi dari segi kebahasaan ini belum lengkap, oleh karena itu perlu ditambah dengan penjelasan lain secara terminologi yang dikemukakan oleh para ahli resolusi konflik, diantaranya, Menurut Laurence Boulle, "mediation is a decision making process in wich the parties are assisted by a mediator, the mediator attempt to improve the process of decision making and to assist the parties the reach an out come to wich of them can assent"4.

Menurut J. Folberg dan A. Taylor, "mediation is the process by wich the participant, together with the assistance of a neutral persons, systematically isolate dispute in order to develop options, consider

${ }^{3}$ Tim Penyusun Kamus Pusat Pembinaan dan Pengembangan Bahasa, 1988, Kamus Besar Bahasa Indonesia, Depdikbud, Jakarta halaman 569.

4 Laurence Boulle, 1996, Mediation: Principle, process, practice, Butterworths, Sydney, halaman 1. alternative, and reach consencual settlement that will accommodate their needs." 5

Menurut Garry Goopaster,

"mediasi sebagai proses negosiasi pemecahan masalah di mana pihak luar yang tidak memihak (imparsial) bekerjasama dengan pihak-pihak yang bersengketa untuk membantu mereka memperoleh kesepakatan perjanjian yang memuaskan."6

Menurut Gunawan Widjaya, mediasi adalah proses penyelesaian sengketa alternatif di mana pihak ketiga yang dimintakan bantuannya untuk membantu proses penyelesaian sengketa bersifat pasif dan sama sekali tidak diberikan wewenang untuk memberikan suatu masukan, terlebih lagi untuk memustukan perselisihan yang terjadi. $^{7}$

Menurut Huala Adolf, mediasi adalah proses melibatkan keikutsertaan pihak ketiga (mediator) yang netral dan independen dalam suatu sengketa. Tujuannya adalah untuk menciptakan adanya suatu kontak atau hubungan langsuang diantara para pihak. Mediator bis negara, individu, organisasi internasional dan lain-lain. ${ }^{8}$

${ }^{5}$ J. Folberg dan A. Taylor, 1984, Mediation: A Comprehensive Guide to Resolving Conflict without Litigation, Cambridge University Press, Cambridge, halaman 7 .

6 Gary Goopaster, 1993, Negosiasi dan Mediasi: Sebuah Pedoman Negosiasi dan Penyelesaian Sengketa Melalui Negosiasi, ELIPS Project, Jakarta halaman 201.

7 Gunawan Widjaya, 2001, Seri Hukum Bisnis: Alternatif Penyelesaian sengketa. Edisi I Cet. I Raja Grafindo Persada, Jakarta,. halaman 2.

8 Huala Adolf, 2004, Hukum Penyelesaian Sengketa Internasional. Cet I, Sinar Grafika, Jakarta,. halaman 120 
Menurut John W. Head,

mediasi adalah suatu prosedur penengahan, seorang mediator bertindak sebagai "kendaraan"untuk berkomunikasi antar pihak sehingga pandangan mereka yang berbeda atas sengketa tersebut dapat dipahami dan mungkin didamaikan, akan tetapi tanggung jawab atas tercapainya perdamaian tetap berada di tangan para pihak sendiri. ${ }^{9}$

Menurut Peraturan Mahkamah Agung Republik Indonesia (Perma) Nomor 1 Tahun 2008 tentang Prosedur Mediasi di Pengadilan, yang disebut dengan mediator adalah pihak netral yang membantu para pihak dalam proses perundingan guna mencari berbagai kemungkinan penyelesaian sengketa tanpa menggunakan cara memutus atau memaksakan sebuah penyelesaian. $^{10}$

Dengan berbagai pengertian mediasi tersebut, dapat dinyatakan bahwa mediasi sesungguhnya merupakan proses penyelesaian sengketa secara netral oleh pihak ketiga yang dilakukan dalam suasana dialog yang terbuka, tidak berpihak, jujur dan tukar pendapat untuk mencapai kata mufakat.

Selanjutnya sebagai pendukung perlu juga dijelaskan tentang arbitrase yang mungkin saja relavan untuk diterapkan dalam penyelesaian sengketa secara adat di Aceh.

Istilah arbitrase berasal dari kata "Arbitrare" (bahasa Latin) yang berarti "kekuasaan untuk penyelesaikan sesuatu perkara menurut kebijaksanaan". Definisi

\footnotetext{
${ }^{9}$ Gatot Sumarsono, 2006, Arbitrase dan Mediasi di Indonesia. PT Raja Gramedia Pustaka Utama, Jakarta, halaman 31-32.

${ }^{10}$ Lihat Perma Nomor 1 Tahun 2008 tentang Prosedur Mediasi di Pengadilan, pasal 1
}

secara terminologi dikemukakan berbedabeda oleh para sarjana saat ini walaupun pada akhirnya mempunyai inti makna yang sama.

Subekti menyatakan bahwa, "arbitrase adalah penyelesaian atau pemutusan sengketa oleh seorang hakim atau para hakim berdasarkan persetujuan bahwa para pihak akan tunduk pada atau menaati keputusan yang diberikan oleh hakim yang mereka pilih." 11

H. Priyatna Abdurrasyid menyatakan bahwa "arbitrase adalah suatu proses pemeriksaan suatu sengketa yang dilakukan secara yudisial seperti oleh para pihak yang bersengketa, dan pemecahannya akan didasarkan kepada bukti-bukti yang diajukan oleh para pihak." 12

H.M.N. Purwosutjipto menggunakan istilah perwasitan untuk arbitrase yang diartikan sebagai suatu peradilan perdamaian, di mana para pihak bersepakat agar perselisihan mereka tentang hak pribadi yang dapat mereka kuasai sepenuhnya diperiksa dan diadili oleh hakim yang tidak memihak yang ditunjuk oleh para pihak sendiri dan putusannya mengikat bagi kedua belah pihak. $^{13}$

Pada dasarnya arbitrase adalah suatu bentuk khusus Pengadilan. Poin penting yang membedakan Pengadilan dan arbitrase adalah bila jalur Pengadilan (judicial settlement) menggunakan satu peradilan permanen atau standing court, sedangkan

\footnotetext{
${ }^{11}$ Subekti, 1992, Arbitrase Perdagangan, Bina Cipta, Bandung, halaman 1.

${ }^{12}$ H. Priyatna Abdurrasyid, 1996, Penyelesaian Sengketa Komersial Nasional dan Internasional) di luar Pengadilan, Makalah, September, halaman 1.

13 H.M.N. Poerwosutjipto, 1992, Pokokpokok Hukum Dagang, Perwasitan, Kepailitan dan Penundaan Pembayaran, Cetakan III, Djambatan, Jakarta, halaman 1.
} 
arbitrase menggunakan forum tribunal yang dibentuk khusus untuk kegiatan tersebut. Dalam arbitrase, arbitrator bertindak sebagai "hakim" dalam mahkamah arbitrase, sebagaimana hakim permanen, walaupun hanya untuk kasus yang sedang ditangani. ${ }^{14}$

Menurut Frank Elkoury dan Edna Elkoury, arbitrase adalah suatu proses yang mudah atau simple yang dipilih oleh para pihak secara sukarela yang ingin agar perkaranya diputus oleh juru pisah yang netral sesuai dengan pilihan mereka di mana keputusan berdasarkan dalil-dalil dalam perkara tersebut. Para pihak setuju sejak semula untuk menerima putusan tersebut secara final dan mengikat. ${ }^{15}$

Sebagai pendukung juga digunakan Kaedah "Al-'Adat muhakkamat". Kedua suku kata tersebut berasal dari bahasa Arab. Al-'urf atau al-'adat berarti kebiasaan atau tradisi yang hidup dalam masyarakat, bisa dibedakan atas dua: al-'urf alshahih (kebiasaan yang selaras dengan syariat) dan al-'urf al-fasid (kebiasaan yang bertentangan dengan syariat). Al-'urf alshahih, oleh sebagian besar ulama dianggap absah sebagai dalil hukum.

Dalam Ilmu Ushul Fiqih terdapat kaidah al-'adat muhakkamat, artinya adat bisa mempengaruhi materi hukum secara proporsional. Hukum Islam tidak memposisikan adat sebagai faktor eksternal

${ }^{14}$ Brierly J. Law, 1983, The Law of Nation, Clarendon Press, Oxford, halaman 347.

${ }^{15}$ Frank Elkoury dan Edna Elkoury, How Arbitration Work, Washington DS., 1974, dikutip dari M. Husseyn dan A. Supriyani Kardono, Kertas Kerja Hukum Ekonomi, Hukum dan Lembaga Arbitrase di Indonesia, Proyek Pengembangan Hukum Ekonomi dan Penyempurnaan Sistem Pengadaan, Kantor Menteri Negara Koordinasi Bidang Ekonomi, Keuangan dan Pengawasan Pembangunan, 1995, hlm.2. non-implikatif, namun sebaliknya, memberikan ruang akomodatif bagi adat. Kenyataan inilah yang menyebabkan hukum Islam bersifat fleksibel.

Kaedah lain juga menerangkan, Muhafazhatu 'ala al-qadim al-shalih wa akhdzu 'ala al-jadidi alashlah (Memelihara hal lama yang baik dan mengambil hal baru yang lebih baik). Maksudnya, kedatangan Islam tidaklah untuk memberangus adat yang baik yang berlaku pada suatu masyarakat. Islam memandang adat yang baik sebagai suatu bentuk kreasi manusia dalam konteks lingkungannya (fisik dan nonfisik). Karena itu, Islam bersifat acceptable pada berbagai bentuk masyarakat yang ada di dunia ini kapanpun juga.

Nabi pernah memberikan contoh antara lain, Pertama, hadis dari Anas bin Malik, ketika Nabi saw ingin menulis surat kepada kerajaan Rum, disampaikan kepada nabi, bahwa mereka tidak akan membaca surat yang tidak mempunyai kop. Lalu baginda pun membuat kop yang terbuat dari perak. Kata Anas, seakan aku masih melihat kilauan kop berkenaan di tangan Nabi saw berukir Muhammad Rasulullah. (HR.Bukhari dan Muslim).

Kedua, Rasulullah juga bersifat fleksibel dalam soal gaya pakaian selagi tidak melanggar batas syari'ah. Beliau menggalakkan warna putih, namun hadishadis menunjukkan baginda juga memakai warna lain. Baginda memakai bermacammacam pakaian dari berbagai negeri seperti Yaman, Mesir dan lain-lain. Bahkan dalam hadis dari al-Mughirah bin Syu'bah, beliau berkata: Sesungguhnya Nabi s.a.w. memakai jubah Rum (ketika itu masih beragama nasroni) - dalam hadis yang 
lain disebut Jubah Syamiah (negeri Syam) yang sempit kedua tangan bajunya. (HR.Bukhari, Muslim, Tirmizi, Nasai dan lain-lain).

Nabi melakukan di atas tentunya memberikan pelajaran yang berharga bagi umatnya bahwa tidak semua adat dan budaya luar itu bersalahan dengan agama. Kata Imam Ibn Qayyim (w. 751H) : "Petunjuk Nabi dalam berpakaian itu adalah memakai apa yang paling bermanfaat (sesuai) untuk badan, paling ringan dan mudah dipakai dan ditanggalkan." (Ibn Qaiyyim, Zad al-Ma'ad, Beirut, Muassasah al-Risalah). Yusuf Al-Qardhawi dalam AlHalal wal Haram fil Islam berpendapat, bahwa adat dan muamalah, bukan Allah pencetusnya, tetapi manusialah yang mencetuskan dan berinteraksi dengannya, sedang Allah datang membetulkan, meluruskan dan membina serta menetapkannya pada suatu waktu dalam halhal yang tidak mengandung mafsadat dan mudharat.

Dengan mengetahui kaidah ini, maka akan tampak cara menetapkan hukumhukum terhadap berbagai kejadian baru, sehingga tidak akan berbaur antara adat dan ibadah dan tidak ada kesamaran bid'ah dengan penemuan-penemuan baru pada masa sekarang. Dimana masing-masing mempunyai bentuk sendiri-sendiri dan masing-masing ada hukumnya secara mandiri.

Dari berbagai adat-istiadat yang berlaku di masyarakat, tidak semuanya bisa diadopsi dengan bebas oleh Islam. Secara umum Ada dua kategori adat, pertama adalah adat shalih (adat yang baik), dan yang kedua adalah adat fasid (adat yang buruk). Untuk kategori yang pertama adalah sebuah tradisi yang tidak bertentangan dengan dalil-dalil syar'i, tidak menghalalkan yang haram, atau menggugurkan kewajiban, mendorong adanya maslahah, dan mencegah timbulnya destruksi social. Sedangkan adat buruk adalah adat yang melanggar aturan agama, dengan menghalalkan yang haram atau mengharamkan yang halal. Adat yang shalih merupakan adat yang diakui dan dibenarkan oleh agama Islam.

Sistem mediasi akan membuat proses penyelesaian sengketa lebih cepat dan murah, serta dapat memberikan akses yang lebih besar kepada para pihak menemukan penyelesaian yang memuaskan dan memenuhi rasa keadilan ${ }^{16}$.

Untuk memastikan proses mediasi berlangsung adil dan damai, di dalam perma tahun 2008 juga telah dicantumkan bahwa para pihak berhak memilih mediator yang sesuai dengan untuk mereka, di antara pilihan-pilihan berikut:

1. Hakim bukan pemeriksa perkara pada pengadilan yang bersangkutan;

2. Advokat atau akademisi hukum;

3. Profesi bukan hukum yang dianggap para pihak menguasai atau berpengalaman dalam pokok sengketa;

4. Hakim majelis pemeriksa perkara; 
5. Gabungan antara mediator yang disebut dalam butir a dan d, atau gabungan butir $\mathrm{b}$ dan

6. d, atau gabungan butir c dan d. ${ }^{17}$

Proses mediasi merupakan alternatif penyelesaian sengketa di luar pengadilan, yang juga diakui keberadaannya di dalam UU nomor 30 Tahun 1999 Tentang Arbitrase Dan Alternatif Penyelesaian Sengketa. Dalam UU yang menjadi dasar hukum adanya arbitrase itu disebutkan:

Sengketa atau beda pendapat perdata dapat diselesaikan oleh para pihak melalui alternatif penyelesaian sengketa yang didasarkan pada itikad baik dengan mengesampingkan penyelesaian secara litigasi di Pengadilan Negeri ${ }^{18}$.

\section{Peradilan Adat}

Peradilan Adat adalah peradilan perdamaian melalui musyawarah mufakat yang dipimpin oleh keuchik di tingkat Gampong dengan anggota Tengku Munasah dan tuha Peut gampong; dan dipimpin oleh imum Mukim di tingkat Mukim dengan anggota imum syik dan para tuha peut mukim $^{19}$;

Proses peradilan adat yang menganut sistem perdamaian walaupun berbeda dasar hukum dengan Mediasi dan Arbitrase tetapi masih memiliki ruh yang sama, yaitu menyelesaikan berbagai sengketa secara damai.

\footnotetext{
${ }^{17}$ Ibid, pasal 8

18 Undang - Undang Republik Indonesia
} Nomor 30 Tahun 1999 Tentang Arbitrase Dan Alternatif Penyelesaian Sengketa, pasal 6

19 Qanun Propinsi Nanggroe Aceh Darussalam Nomor 3 tahun 2004 tentang Pembentukan susunan dan tata kerja Majlis Adat Aceh/MAA, pasal 1
Pengakuan penyelesaian sengketa secara damai oleh peradilan adat, juga tersirat dalam UU nomor 30 tahun 1999, yang mengharuskan Pengadilan Negeri untuk menolak dan tidak akan campur tangan di dalam suatu penyelesaian sengketa yang telah ditetapkan melalui arbitase. ${ }^{20}$

Wewenang yang sangat besar yang diberikan kepada proses perdamaian tersebut harus pula diikuti dengan perilaku mediator yang netral dan tidak memihak, supaya penyelesaian sengketa secara damai tidak menimbulkan ketidakadilan bagi para pihak.

Untuk itu agar keberadaan mediator, atau perantara, dapat diterima maka yang bersangkutan harus mempunyai sifat-sifat berikut:

1. Amanah

2. Jujur

3. Tidak memihak

4. Tidak punya kepentingan pribadi

5. Bertekad untuk menyelesaikan pertikaian yang dapat diterima kedua belah pihak

6. Ramah dan percaya diri

7. Mampu mengendalikan emosi para pihak

8. Mampu memahami kehendak dan aspirasi para pihak

9. Mampu menerjemahkan keinginan pihak yang satu kepada pihak yang lainnya dengan menggunakan bahasa yang santun dan sejuk

10. Mampu melakukan pendekatan yang berunsur agama, sosial, dan psikologi

11. Piawai dalam menggunakan bahasa yang menyejukkan

${ }^{20}$ ibid, pasal 11 
12. Mampu menggunakan "narit maja" secara tepat ${ }^{21}$.

Dengan terpenuhi unsur di atas barulah Mediator dipercaya menjalankan fungsinya yang besar tersebut. Fuller dalam Leonard L. Riskin dan James E. Westbrook menyebutkan 7 (tujuh) fungsi mediator, yaitu: Sebagai katalisator (catalyst), sebagai pendidik (educator), sebagai penerjemah (translator), sebagai narasumber (resource person), sebagai penyandang berita jelek (bearer of bad news), sebagai agen realitas (agent of reality) dan sebagai kambing hitang (scapegoaf). ${ }^{22}$

Dalam pelaksanaannya Peran dan fungsi mediator, atau perantara, dapat dijelaskan sebagai berikut:

1. Membantu para pihak untuk menyadari bahwa sengketa bukan sebuah pertarungan untuk dimenangkan, tetapi untuk diselesaikan.

2. Menyusun dan mengusulkan alternatif pemecahan masalah.

3. Membantu para pihak untuk menganalisis alternatif pemecahan masalah. $^{23}$

Proses mediasi dibagi ke dalam tiga tahap, yaitu tahap pra mediasi, tahap pelaksaaan mediasi, dan tahap akhir mediasi.

Pada tahap pra mediasi mediator melakukan beberapa langkah antara lain,

Cit, halaman 24

${ }^{21}$ Tim Proyek Keadilan Aceh UNDP, Op.

${ }^{22}$ Ronal S. Kraybill, dkk, 2006, Peace Skill, Panduan Mediator terampil Membangun Perdamaian. Yogyakarta, Kanisius,Halaman 95-96

${ }^{23}$ Tim Proyek Keadilan Aceh UNDP, 2008, Pedoman Peradilan Adat Di Aceh Untuk Peradilan Adat Yang Adil Dan Akuntabel, Majelis Adat Aceh, Banda Aceh, halaman 25 membangun kepercayaan diri, menghubungi para pihak, menggali dan memberikan informasi awal mediasi, fokus pada masa depan, mengoordinasikan pihak bertikai, mewaspadai perbedaan budaya, menentukan siapa yang hadir, menentukan tujuan pertemuan, kesepakatan waktu dan tempat dan menciptakan rasa aman bagi kedua belah pihak untuk bertemu dan membicarakan perselisihan mereka. ${ }^{24}$ Tahap pelaksanaan mediasi adalah tahap di mana pihak-pihak yang bertikai sudah berhadapan satu sama lain dan memulai proses mediasi. Dalam tahap ini, terdapat beberapa langkah penting antara lain, sambutan pendahuluan mediator, presentasi dan pemaparan kisah para pihak, mengurutkan dan menjernihkan permasalahan, berdiskusi dan negosiasi masalah yang disepakati, menciptakan opsiopsi, menemukan butir kesepakatan dan merumuskan keputusan, mencatat dan menuturkan kembali keputusan dan penutup mediasi.

Tahap Akhir Hasil Mediasi. Tahap ini merupakan tahap di mana para pihak hanyalah menjalankan hasil-hasil kesepakatan, yang telah mereka tuangkan bersama dalam suatu perjanjian tertulis.

Agar terciptanya keseimbangan sosial, Keuchik dalam menyelesaikan perkara harus mengacu pada asas-asas berikut:

1. kedudukan pihak-pihak yang bertikai adalah sama,

2. peradilan dilaksanakan dengan hakim kolegial dengan hakim terdiri dari geuchik, imuem meunasah, dan tuha peut,

\footnotetext{
${ }^{24}$ Ronal S. Kraybill, dkk, Op. Cit, Hlm. 63-
} 67. 
3. dalam proses penegakan hukum harus diperhatikan pula jangan sampai dengan putusan itu menimbulkan perpecahan dalam masyarakat,

4. penyelesaian diwujudkan dalam bentuk perdamaian ${ }^{25}$.

Pertemuan dengan para pihak harus dilakukan secara terpisah dan isi pembicaraan bersifat rahasia bagi pihak lain. Tujuan petemuan terpisah itu adalah:

1. Untuk menjalin hubungan lebih intensif dengan para pihak

2. Membangun saling kepercayaan salah satu pihak untuk mengungkapkan kepentingan yang tidak ingin mereka ungkapkan di hadapan mitra rundingnya

3. Memungkinkan mediator untuk mencari informasi tambahan, mengetahui garis dasar dan menyelidiki agenda tersembunyi

4. Membantu mediator dalam memahami motivasi para pihak dan prioritas mereka dan membangun empati serta kepercayaan secara individual

5. Memberikan para pihak waktu dan kesempatan yang cukup untuk menyalurkan emosi kepada mediator tanpa membahayakan kemajuan mediasi

25

T. Juned, 2001, Penerapan Sistem dan Asas-asas Peradilan Hukum Adat Dalam Penyelesaian Perkara, dalam M. Isa Sulaiman dan H. T. Syamsuddin (ed.), Pedoman Adat Aceh: Peradilan dan Hukum Adat, Banda Aceh, LAKA, halaman 18-23
6. Memungkinkan mediator untuk menguji seberapa realistis pilihan-pilihan yang diusulkan

7. Memungkinkan mediator untuk mengarahkan para pihak guna melaksanakan perundingan yang berguna

8. Memungkin mediator dan para pihak untuk mengembangkan dan empertimbangkan alternatifalternatif baru

9. Memungkinkan mediator untuk meyakinkan para pihak untuk menerima penyelesaian

10. Menyediakan ruang dan waktu yang memadai kepada para pihak supaya dapat menyampaikan persoalannya secara pribadi mengenai:

a. Apa yang sedang terjadi

b. Apa yang dirasakan

c. Bagaimana hal ini bisa diselesaikan

d. Apakah proses mediasi dengan pendekatan samasama menang (win-win) bisa membantu.

\section{Pelaksanaan Putusan Peradilan Adat}

Pelaksanaan putusan adat yang dihasilkan melalui mediasi dalam peradilan adat yang berupa sanksi adat, segera dilakukan setelah putusan disampaikan oleh Keuchik atau Mukim, terutama terhadap sanksi adat yang berupa nasehat, peringatan, dan permintaan maaf.

Untuk sanksi ganti rugi pelaksanaan putusannya lebih longgar yaitu tergantung 
kepada kemampuan ekonomi pelanggar untuk menyediakan ganti rugi tersebut ${ }^{26}$.

Demikian pula, dalam hal sanksi adat yang berupa pengusiran dari Gampong, maka pelaksanaannya tidak dilakukan segera setelah putusan tersebut dibacakan, tetapi kepada pelanggar norma adat itu masih diberikan waktu secukupnya untuk bersiap-siap meninggalkan kampung halamannya, kadang-kadang sanksi itu berlaku selama yang dihukum belum insaf atau mengakui kesalahannya. Kalau ia sudah mau mengakui kesalahannya maka ia boleh kembali lagi ke Gampong tersebut dengan turut membayar denda sebagai sanksi adat ${ }^{27}$.

\section{Sanksi Adat}

Dalam hukum adat semua jenis pelanggaran memiliki jenjang penyelesaian yang selalu dipakai dan ditaati masyarakat. Hukuman/ sanksi dalam adat Aceh tidak langsung diberikan begitu saja meskipun dalam hukum adat juga mengenal istilah denda.

Dalam hukum adat jenis penyelesaian masalah dan sanksi dapat dilakukan terlebih dahulu dengan menasehati, selanjutnya teguran, lalu pernyataan maaf oleh yang bersalah di hadapan orang banyak di meunasah atau mesjid, kemudian baru dijatuhkan denda. ${ }^{28}$.

Di dalam Qanun Aceh disebutkan jenis-jenis sanksi yang dapat dijatuhkan

26 Sesuai dengan Wawancara dengan $\mathrm{H}$. Adnan Harun, Mukim Pagar Air, Aceh Besar, tanggal 28 Juni 2012, jam 14.00 WIB.

27 Menurut keterangan Bukhari, Keuchik Gampong Lubok Batee, Kemukiman Pagar Air, Aceh Besar, tanggal 26 Juni 2012, jam 21.00 WIB

28 Wawancara dengan Azhar Ismail, Keuchik Gampong Bakoy, 21 Juni 2010, pukul 09.00 WIB dalam penyelesaian sengketa adat sebagai berikut:

a. nasehat;

b. teguran;

c. pernyataan maaf;

d. sayam;

e. diyat;

f. denda;

g. ganti kerugian;

h. dikucilkan oleh masyarakat gampong atau nama lain;

i. dikeluarkan dari masyarakat gampong atau nama lain;

j. pencabutan gelar adat; dan

k. bentuk sanksi lainnya sesuai dengan adat setempat ${ }^{29}$.

Untuk memastikan sanksi tersebut berjalan sesuai dengan keputusan peradilan adat, maka diharuskan kepada keluarga pelanggar adat ikut bertanggung jawab atas terlaksananya sanksi adat yang dijatuhkan kepada anggota keluarganya ${ }^{30}$.

Walau demikian, selama ini hukuman denda, ganti rugi, mengaku bersalah dan minta maaf merupakan hukuman yang kelihatannya dikenal luas ${ }^{31}$

29 Qanun Aceh Nomor 9 Tahun 2008 Tentang Pembinaan Kehidupan Adat Dan Adat Istiadat, pasal 16

${ }^{30}$ Ibid, pasal 16 ayat 2

31 Al-Yasa' Abu Bakar, 2007, Islam, Hukum, dan Masyarakat di Aceh; Tajdid Syari'at Dalam Negara Bangsa, Makalah disampaikan pada KonfrensiInternasional I Studi Aceh dan Asia Tenggara di Banda Aceh tanggal $24-27$ Februari 2007 
Dewasa ini ada keinginan kuat dari para penyelenggara peradilan adat bahwa sebaiknya penetapan putusan adat dibuat secara tertulis, karena dengan bentuk tertulis akan menambah bobot putusan itu sendiri. Di samping itu, pemantauan terhadap putusan tersebut akan lebih mudah diawasi. Diharapkan juga agar salinan putusan tersebut disampaikan kepada yang bersangkutan (para pihak), lembaga mukim, dan pihak kepolisian. Hal ini, bertujuan agar mereka mengetahui kalau suatu perkara telah diselesaikan di tingkat peradilan Gampong dan mereka tidak perlu memeriksa kembali, kecuali dalam kasuskasus tertentu yang memang bukan merupakan kewenangan Gampong. Jika perkara ini di kemudian hari akan dimintakan banding, sebuah keputusan tertulis akan menjadi bukti penting dalam penentuan perkara banding.

Setelah putusan didokumentasikan, termasuk ditandatangani oleh semua pihak, detail-detail dan data mengenai kasus yang sedang ditangani harus dicatat dalam Buku Induk Registrasi.

Detail-detail dan data yang perlu dicatat termasuk: nomor kasus, tanggal pelaporan, nama pelapor, jenis kasus, uraian singkat pokok perkara, tanggal penyelesaiannya (jika ada) dan uraian singkat putusan perdamaian $^{32}$.

\section{Koordinasi dengan Penegak Hukum}

Koordinasi antara tokoh adat dengan aparat penegak hukum dilakukan dengan baik supaya proses peradilan adat tidak tumpang tindih dengan proses penegakan hukum secara umum. Untuk itu dalam Cit, halaman 28
Qanun Aceh sudah ditegaskan bahwa setiap aparat yang bertugas di Aceh harus memahami dan menghargai tatanan adat dan adat istiadat $\mathrm{Aceh}^{33}$.

Bahkan lebih dari itu setiap pejabat/ aparat Pemerintah Aceh dan pemerintah kabupaten/ kota harus memahami, membina, dan menghargai tatanan adat dan adat istiadat masyarakat setempat ${ }^{34}$.

Dalam Surat Keputusan Bersama Gubernur, Kepala Kepolisian Daerah Aceh, dan Ketua Majelis Adat Aceh, nomor 189/677/2001 1054/MAA/XII/2011, B/121/I/2012, tanggal 20 Desember 2011, juga disebutkan bahwa Aparat Kepolisian memberikan kesempatan agar setiap sengketa/ perselisihan yang masuk dalam ranah adat diselesaikan terlebih dahulu melalui peradilan adat Gampong dan Mukim $^{35}$.

Kemuadian dalam SKB tersebut juga menegaskan kepada semua pihak wajib menghormati penyelenggaraan peradilan adat Gampong dan Mukim di Aceh. ${ }^{36}$

\section{Pelimpahan Kasus Ke Pengadilan}

Kasus sengketa adat yang tidak ditangani melalui mediasi dalam peradilan adat, dapat dilimpahkan ke pengadilan. Pelimpahan tersebut dapat terjadi karena beberapa hal:

${ }^{33}$ Lihat Qanun Aceh Nomor 9 Tahun 2008 Tentang Pembinaan Kehidupan Adat Dan Adat Istiadat, pasal 10 ayat 2

${ }^{34}$ Ibid, pasal 10 ayat 3

35 Lihat Keputusan Bersama Gubernur, Kepala Kepolisian Daerah Aceh, dan Ketua Majelis Adat Aceh, nomor 189/677/2001, 1054/MAA/XII/2011, B/121/I/2012, poin 2

${ }^{36}$ Ibid, poin 3 
1. Bukan kompetensi dan jurisdiksi adat;

2. Para pihak tidak mau menyelesaikannya melalui peradilan adat; dan

3. Hukum Adat tidak mampu menyelesaikannya $^{37}$;

Kasus-kasus yang bukan kewenangan (kompetensi) peradilan adat meskipun terjadi dalam jurisdiksi adat seperti pembunuhan, perzinahan, pemerkosaan, narkoba, ganja dan sejenisnya, pencurian berat, suversif, penghinaan terhadap pemerintah yang sah (Presiden dan Gubernur), Kecelakaan lalu lintas berat (kematian), Penculikan, dan Perampokan bersenjata, maka dalam hal ini Keuchik segera memberitahukan kepada pihak kepolisian di tingkat kecamatan (polsek). Pemberitahuan tersebut dapat dilakukan secara lisan maupun tulisan.

Dalam hal para pihak tidak mau menyelesaikan perkaranya melalui peradilan adat Gampong, maka yang bersangkutan dapat membawa kasusnya ke pengadilan formal yang diikuti oleh surat keterangan pelepasan kasus dari Keuchik. Surat keterangan pelepasan kasus tersebut sangat penting sebagai dasar bagi peradilan formal untuk memeriksa kasus tersebut.

\section{Pendaftaran Keputusan Adat di Pengadilan}

Keputusan adat yang dihasilkan melalui mediasi di di peradilan adat gampong dan mukim memiliki kekuatan hukum final dan mengikat, hal itu sesuai dengan Qanun 5

\footnotetext{
${ }^{37}$ Ibid, halaman 30
}

Tahun 2003 tentang Pemerintahan Desa Dalam Propinsi NAD, pasal 12 ayat 3 . Namun dalam pelaksanaannya diperlukan upaya dari para pemangku adat untuk melakukan koordinasi dengan pengadilan supaya terbangun hubungan kerja yang sinergis dalam penanganan kasus serupa jika muncul kembali.

Selama ini hasil putusan peradilan adat dalam penyelesaian sengketa tidak didaftarkan di pengadilan negeri, sehingga potensi mencuatnya kembali kasus tersebut di kemudian hari di pengadilan formal masih terbuka, apalagi pihak pengadilan belum tentu mengetahui kasus tersebut sudah pernah diselesaikan di tingkat peradilan gampong atau mukim.

Untuk itu tidak salahnya kalau dilakukan integrasi antara sistem peradilan adat Aceh dengan Peraturan Mahkamah Agung Republik Indonesia Nomor 01 Tahun 2008 Tentang Prosedur Mediasi Di Pengadilan, supaya tidak ada tumpang tindih dalam pelaksanannya.

Untuk mengkolaborasi kedua sistem tersebut bisa dilakukan dengan mendaftarkan semua hasil putusan adat ke pengadilan. Karena Perma tersebut telah memberikan peluang

kepada para pihak untuk mengajukan kesepakatan perdamaian kepada hakim untuk dikuatkan dalam bentuk akta perdamaian $^{38}$.

Di dalam undang-undang Republik Indonesia Nomor 30 Tahun 1999 Tentang Arbitrase Dan Alternatif Penyelesaian Sengketa juga ditetapkan hal yang sama, bahwa semua hasil perdamaian yang

${ }^{38}$ Lihat Peraturan Mahkamah Agung Republik Indonesia Nomor 01 Tahun 2008 Tentang Prosedur Mediasi Di Pengadilan, pasal 17 
dilakukan melalui arbitrase harus didaftarkan di pengadilan.

Di dalam UU itu disebutkan bahwa kesepakatan penyelesaian sengketa atau beda pendapat secara tertulis adalah final dan mengikat para pihak untuk dilaksanakan dengan itikad baik serta wajib didaftarkan di Pengadilan Negeri dalam waktu paling lama 30 (tiga puluh) hari sejak penandatanganan ${ }^{39}$.

Dengan didaftarkannya hasil putusan adat di pengadilan akan menjamin adanya kepastian hukum terhadap putusan adat tersebut sehingga memiliki kekuatan hukum tetap dan diakui keabsahannya oleh sistem adat dan sistem peradilan formal.

\section{DAFTAR PUSTAKA}

\section{Buku-Buku}

Badruzzaman Ismail, 2002 ,Fungsi Meunasah Sebagai Lembaga ( Hukum ) Adat di Aceh Besar, Tesis Magister Hukum, Program Pasca Sarjana Universitas Sumatra Utara, Medan

Badruzzaman Ismail, 2002, Mesjid dan Adat Meunasah Sebagai Sumber Energi Budaya Aceh, Banda Aceh, Majelis Pendidikan Daerah Provinsi NAD,.

C. Snouck Hurgronje, 1996, ACEH Rakyat dan Adat Istiadat, Jakarta: INIS

Gary Goopaster, 1993, Negosiasi dan Mediasi: Sebuah Pedoman Negosiasi dan Penyelesaian Sengketa Melalui Negosiasi, ELIPS Project, Jakarta

${ }^{39}$ Lihat UU Nomor 30 Tahun 1999 Tentang Arbitrase Dan Alternatif Penyelesaian Sengketa
Gatot Sumarsono, 2006, Arbitrase dan Mediasi di Indonesia. PT Raja Gramedia Pustaka Utama, Jakarta

Gunawan Widjaya, 2001, Seri Hukum Bisnis: Alternatif Penyelesaian sengketa. Edisi I Cet. I Raja Grafindo Persada, Jakarta

H. Badruzzaman dkk, 2003, Eksposa Majelis Adat Aceh Provinsi NAD, Banda Aceh: MajelisAdat Aceh

Huala Adolf, 2004, Hukum Penyelesaian Sengketa Internasional. Cet I, Sinar Grafika, Jakarta

Isa Sulaiman, M, Dr, dan Syamsuddin MS, 2002, Pedoman Adat Aceh, Peradilan dan Hukum Adat, Penerbit LAKA Prov. NAD, 2002, Edisi II

J. Folberg dan A. Taylor, 1984, Mediation: A Comprehensive Guide to Resolving Conflict without Litigation, Cambridge University Press, Cambridge

Laurence Boulle, 1996, Mediation: Principle, process, practice, Butterworths, Sydney

Leena Avonius, dkk, 2010, Adat dalam dinamika politik Aceh, Banda Aceh, ICAIOS.

Lorna Gilmour, 2007, Penny Hand dan Cormac McKeown (eds), Collins English Dictionary and Thesaurus, Third Edition, Harper Collins Publishers, Great Britain 
M. Isa Sulaiman dan H. T. Syamsuddin (ed.), 2001, Pedoman Adat Aceh: Peradilan dan Hukum Adat, Banda Aceh, LAKA

Ronal S. Kraybill, Alice Frazer Evans dan Robert A. Evans, 2006, Peace Skill, Panduan Mediator terampil Membangun Perdamaian.Yogyakarta, Kanisius

Said Agil Husein al Munawar, 1994, Pelaksanaan Arbitrase di Dunia Islam,Dalam Arbitrase Islam di Indonesia,BAMUI \& BMI, Jakarta

Sanusi M. Syarif.2005. Gampong dan Mukim di Aceh: Menuju Rekonstruksi Pasca Tsunami, Pustaka Latin. Bogor

Sufi, Rusdi. 2002, Adat Istiadat Masyarakat Aceh, Dinas Kebudayaan Provinsi Nanggroe Aceh, Banda Aceh.

Syahrizal Abbas, 2009, Mediasi dalam Perspektif Hukum Syari'ah, Hukum Adat dan Hukum Nasional, Kencana Prenada Media Group, Jakarta

Taqwaddin, 2009, Penyelesaian Perkara secara Adat Aceh, paper Fakultas Hukum Universitas Syiah Kuala Darussalam, Banda Aceh.

Teer Har, dalam Badruzzaman Ismail, 2007,Mesjid dan Adat Meunasah Sebagai Sumber Energi Budaya Aceh, Banda Aceh, MAA-Nanggroe Aceh Darussalam,

Tim Penyusun Kamus Pusat Pembinaan dan Pengembangan Bahasa, 1988, Kamus Besar Bahasa Indonesia, Depdikbud, Jakarta
Tim Proyek Keadilan Aceh UNDP, 2008, Pedoman Peradilan Adat Di Aceh Untuk Peradilan Adat Yang Adil Dan Akuntabel, Majelis Adat Aceh, Banda Aceh,

\section{PERUNDANG-UNDANGAN}

Kitab Undang-Undang Hukum Pidana Undang-undang nomor 11 tentang pemerintahan Aceh

Undang-undang Republik Indonesia Nomor 30 Tahun 1999 Tentang Arbitrase Dan Alternatif Penyelesaian Sengketa

Peraturan Mahkamah Agung Republik Indonesia Nomor 02 Tahun 2012 Tentang Penyesuaian Batasan Tindak Pidana Ringan Dan jumlah denda dalam KUHP

Perma Nomor 1 Tahun 2008 tentang Prosedur Mediasi di Pengadilan

Qanun Aceh Nomor 9 Tahun 2008 Tentang Pembinaan Kehidupan Adat Dan Adat Istiadat

Qanun Provinsi Nanggroe Aceh Darussalam Nomor 5 Tahun 2003 Tentang Pemerintahan Gampong Dalam Provinsi Nanggroe Aceh Darussalam

Qanun Nomor 4 Tahun 2003 Tentang Pemerintahan Mukim Dalam Provinsi Nanggroe Aceh Darussalam

Qanun Propinsi Nanggro Aceh Darussalam Nomor 3 tahun 2004 tentang Pembentukan susunan dan tata kerja Majelis Adat Aceh/MAA

Qanun Aceh nomor 5 Tahun 2003 tentang Pemerintahan Desa Dalam Propinsi NAD 
Qanun Aceh Nomor 10 Tahun 2008

Tentang Lembaga-lembaga Adat

Qanun Aceh No 3 Tahun 2009 tentang Tata

Cara Pemilihan Imeum Mukim.

Keputusan Bersama Gubernur, Kepala

Kepolisian Daerah Aceh, dan Ketua Majelis Adat Aceh, nomor 189/677/2001, 1054/MAA/XII/2011, $\mathrm{B} / 121 / \mathrm{I} / 2012$, tanggal 20 Desember 2011 